\title{
TRANSFORMING PLANT WASTES ALONG WITH CATTLE DUNG AND OTHER SUBSTRATES INTO ORGANIC WEALTH THROUGH PARTIAL DECOMPOSITION AND VERMI COMPOSTING
}

\author{
AMARESH DAS, G. G. PATEL \& M. C. PATEL
}

Department of Soil Science, Navsari Agricultural University, Navsari Gujarat, India

\section{ABSTRACT}

An experiment was conducted at LRS farm of NAU, Navsari during 2008 \& 2009 in order to convert Sugarcane trash (ST), banana pseudo stem (BPS) wast material along with 7 to 10 days old cattle dung (CD), fish meal (FM), Subabul leaves/ twigs (SB) and rock phosphate (RP) into organic wealth i.e., vermicompost through partially decomposition and sub sequently vermicomposting following twelve combination of treatments $\{1) T_{1}$ : Absolute control $\left.(100 \% C D), 2) T_{2}:(100 \% C D+R P), 3\right) T_{3}:(C D 50 \% w / w+F M 50 \% w / w+R P) T_{4}:(C D 50 \% w / w+S T 50 \% w / w+R P) T_{5}:$ $(C D 50 \% \quad w / w+S B \quad 50 \% \quad w / w+R P), T_{6}:(C D \quad 50 \% \quad w / w+B P S \quad 50 \% \quad w / w+R P), T_{7}:(C D \quad 50 \% w / w+F M \quad 25 \% \quad w / w+S T 25 \%$ $w / w+R P) T_{8}:(C D 50 \% w / w+F M 25 \% w / w+S B 25 \% w / w+R P), T_{9}:(C D 50 \% w / w+F M 25 \% w / w+B P S 25 \% w / w+R P), T_{10}:$ $(C D 50 \% w / w+S T 25 \% w / w+S B 25 \% w / w+R P), T_{11}:(C D 50 \% w / w+S T 25 \% w / w+B P S 25 \% w / w+R P)$ and $T_{12}:(C D 50 \%$ $w / w+S B 25 \% w / w+B P S 25 \% w / w+R P\}$ under completely randomized design (CRD). Raw materials were placed in heap (3 m length $\times 1.5 \mathrm{~m}$ width $\times 1 \mathrm{~m}$ height) in 6-7 layers (each of $15 \mathrm{~cm}$ height). Slurry of decomposing culture was thoroughly mixed with each layer and allowed for partial decomposition for one month and then the same material was allowed for vermicomposting for 55 days maintaining moisture level to about 55\%. Six representative samples were drawn from each treatment for analysis purposes. Pooled results revealed that significantly the lowest $C: N$ ratio (13:1) and the highest total Nitrogen content $(3.22 \%)$ were obtained under $T_{6}$. i.e. under $50 \%(w / w)$ cattle dung $+50 \%(w / w)$ banana pseudo stem $+5 \%(w / w)$ rock phosphate treatment followed by $T_{11}$ i.e. $50 \%(w / w)$ cattle dung $+25 \%(w / w)$ sugarcane trash $+25 \%(w / w)$ banana pseudo stem $+5 \%(w / w)$ rock phosphate treatment. It was observed that the vermicompost prepared under $T_{6}$ treatment had higher $N$ content, comparatively lower $C: N$ ratio, marginally adequate macro, secondary, micro nutrients along with significantly low heavy metal content $(\mathrm{Cd}, \mathrm{Pb}$ and $\mathrm{Ni}$ ) as compared to manure prepared under $T_{11}$. However, significantly the lowest Co was recorded in end product prepared under $T_{11}$. Hence, vermicompost prepared under treatment $T_{6}$ was considered as the most superior over others followed by manure (vermicompost) prepared under $T_{11}$.

KEYWORDS: Plant Wastes, Cattle Dung, Other Substrates, Decomposing Culture, Vermicomposting \& Organic Wealth

Received: Jul 04, 2017; Accepted: Jul 22, 2017; Published: Jul 26, 2017; Paper Id.: IJASRAUG201756

\section{INTRODUCTION}

Availability of FYM has become limited now-a-days. Further, nutrient content in FYM is also low, as compared to other organic manures like, vermicompost and compost, etc. India, being a vast country has enormous sources of organic plant wastes. Thus, it is of prime need to utilize such huge wastes as are available in this country to transform them into enriched manure wealth through partial decomposition and vermin-composting processes or so for the purpose of its fruitful use in agriculture for improving crop yield, sustaining soil health and 
overall environmental stability. Moreover, Central as well as State Governments are emphasizing on the addition of as much organic manure as possible on soil apart from inorganic fertilizers to maintain not only the soil health but also to sustain crop productivity. Inorganic fertilizers are increasingly becoming costly day by day. Besides, the availability of right fertilizer in right time and that too in requisite quantum to the farmers is a real problem. Vermi-composting is a process by which various organic plant wastes, substrates /raw materials etc. can most effectively be transformed into nutrient -rich organic product (vermicompost), by the activities of specific species of earthworms. Transformation of huge plant waste materials into nutrient-rich manure- wealth, would also save huge exchequer of poor farmers of our country, which they otherwise could have expensed on purchase of inorganic fertilizer (Das, 2007). Considering all the points, the present investigation was carried out in order to transform some pant wastes materials along with cattle dung and some other substrates into organic - wealth through first by partial decomposition and subsequently by vermi-composting for fruitful use in agriculture.

\section{MATERIALS AND METHODS}

An experiment was carried out on the transformation of Sugarcane trash (ST), banana pseudo stem (BPS) waste materials into organic wealth / vermicompost at Live-Stock Research Station farm of Navsari Agricultural University, Navsari during 2008 \& 2009, by using along with them other raw materials like, 7-10 days old cattle dang and other substrate like, Subabul leaves / twigs (SB), Rock phosphate (RP) and Fish meal (FM) following by partial decomposition and then vermicomposting process. Twelve combination of treatments e.g. 1) $\mathbf{T}_{1}$ : Absolute control (100\% CD) , 2) $\mathbf{T}_{2}$ : (100\% CD+RP), 3) $\mathbf{T}_{3}:(\mathrm{CD} 50 \% \mathrm{w} / \mathrm{w}+\mathrm{FM} 50 \% \mathrm{w} / \mathrm{w}+\mathrm{RP}) \mathbf{T}_{4}:(\mathrm{CD} 50 \% \mathrm{w} / \mathrm{w}+\mathrm{ST} 50 \% \mathrm{w} / \mathrm{w}+\mathrm{RP}) \mathbf{T}_{5}:(\mathrm{CD} 50 \% \mathrm{w} / \mathrm{w}+\mathrm{SB}$ $50 \% \mathrm{w} / \mathrm{w}+\mathrm{RP}), \mathbf{T}_{\mathbf{6}}:(\mathrm{CD} 50 \% \mathrm{w} / \mathrm{w}+\mathrm{BPS} 50 \% \mathrm{w} / \mathrm{w}+\mathrm{RP}), \mathbf{T}_{7}:(\mathrm{CD} 50 \% \mathrm{w} / \mathrm{w}+\mathrm{FM} 25 \% \mathrm{w} / \mathrm{w}+\mathrm{ST} 25 \% \mathrm{w} / \mathrm{w}+\mathrm{RP}) \mathrm{T} \mathbf{8}:(\mathrm{CD} 50 \%$ $\mathrm{w} / \mathrm{w}+\mathrm{FM} 25 \% \mathrm{w} / \mathrm{w}+\mathrm{SB} 25 \% \mathrm{w} / \mathrm{w}+\mathrm{RP}), \mathbf{T}_{\mathbf{9}}:(\mathrm{CD} 50 \% \mathrm{w} / \mathrm{w}+\mathrm{FM} 25 \% \mathrm{w} / \mathrm{w}+\mathrm{BPS} 25 \% \mathrm{w} / \mathrm{w}+\mathrm{RP}), \mathbf{T}_{10}:(\mathrm{CD} 50 \% \mathrm{w} / \mathrm{w}+\mathrm{ST}$ $25 \% \mathrm{w} / \mathrm{w}+\mathrm{SB} 25 \% \mathrm{w} / \mathrm{w}+\mathrm{RP}), \mathbf{T}_{\mathbf{1 1}}:(\mathrm{CD} 50 \% \mathrm{w} / \mathrm{w}+\mathrm{ST} 25 \% \mathrm{w} / \mathrm{w}+\mathrm{BPS} 25 \% \mathrm{w} / \mathrm{w}+\mathrm{RP})$ and $\mathbf{T}_{\mathbf{1 2}}:(\mathrm{CD} 50 \% \mathrm{w} / \mathrm{w}+\mathrm{SB} 25 \%$ $\mathrm{w} / \mathrm{w}+\mathrm{BPS} 25 \% \mathrm{w} / \mathrm{w}+\mathrm{RP}$ ) were followed. The experiment was conducted in completely randomized design (CRD) with no replication. ST, BPS and SB were chopped to about 2-3 size before use in treatments for making organic product/ vermicompost. The reason for using rock phosphate as raw material was to improve the phosphorus content in the end product/ vermicompost. Expect $\mathrm{T}_{1}$, in all the treatments from $\mathrm{T}_{2}$ to $\mathrm{T}_{12}$, rock phosphate (5\% w/w of raw material) was added initially with raw materials. In all the treatments raw materials were first decomposed partially for one month by the use of slurry of decomposing culture obtained from Vasantrao Sugarcane Institute, Pune and then earthworms were incorporated in all the treatments for making vermicompost or enriched organic product. In $\mathrm{T}_{1}$ (Absolute Control), no RP was applied, but only slurry of decomposing culture was applied for decomposition.

\section{Preparation of Slurry of Decomposing Cultural Material}

$1 \mathrm{~kg}$ of decomposing cultural material was mixed with $80 \mathrm{~kg}$ of urea and $100 \mathrm{~kg}$ of Single Super Phosphate with $100 \mathrm{~kg}$ cattle dung, and was transformed into slurry with water for mixing with one ton of raw materials for their decomposition.

\section{Preparation of Vermicompost (Organic Manure-Wealth)}

Partial decomposition of raw materials was started, placing raw materials in the heap / bed form \{3 (L) X 1.5 (W) $\mathrm{X} 1 \mathrm{~m}(\mathrm{H})$ \}, on a slightly elevated ground. First, a thin layer of cattle dung was spread right at the bottom of bed and above that raw materials as per treatment (chopped to about $2-3 \mathrm{~cm}$ size) were spread at the bottom of the heap/bed. Then this 
bottom layer was thoroughly moistened with water to allow the material to soak as much as water. Then requisite quantity of slurry of decomposing cultural materials was mixed properly with the raw materials and then again water was sprinkled on it. This way the lowermost bottom layer of raw materials of each treatment was made ready for partial decomposition. Raw materials were used as much quantity as possible, to maintain the height of each layer to about 15 cms. Subsequently, second, third, fourth, fifth and sixth layers were imposed, one above the other layer, following the same procedure so long as the upper surface of heap (materials) reached to about $0.5 \mathrm{~m}$ height above ground level. The upper surface of the heap was covered with a thin (about $3 \mathrm{~cm}$ ) layer of cattle dung - slurry and then covered up by gunny bags to avoid direct sunlight on the heap. The raw materials in the heap were allowed to decompose partially for a month maintaining optimum moisture level around 60\% with two intermittent turnings. Then Earthworms (Sp. Eudrilus enginae) were inoculated @ $500 \mathrm{gm} / \mathrm{m} 3$ of raw material in each treatment making holes at different positions / sites on the heap and then was allowed to mature maintaining a moisture level to about 55\%. The end products (vermicompost) under all the treatments were harvested at 55 days. Six Samples of end products from each treatment were collected from different positions of the same heap /bed as repetitions for analysis. All the samples were analyzed for $\mathrm{pH}, \mathrm{EC}, \mathrm{OC}$, total $\mathrm{N}$ and $\mathrm{C}: \mathrm{N}$ ratio, total $\mathrm{P}, \mathrm{K}, \mathrm{Ca}$, and $\mathrm{Mg}$ content and also for total $\mathrm{Na}, \mathrm{Fe}, \mathrm{Zn}, \mathrm{Mn}$ and $\mathrm{Cu}$ content for both the years. Data were analyzed statistically as based on CRD. PH and EC were determined in 1: 10:: vermicompost : water ratio using pH meter and EC meter, respectively. Organic Carbon was determined by dry combustion method (Jackson et. al. 1973). Total Nitrogen was determined by chromic acid method (Trivedi et. al. 1999). The samples from prepared end products (vermicompost) obtained from different treatments were digested separately in di-acid mixture $\left(\mathrm{HNO}_{3}: \mathrm{HClO}_{4}:: 10: 4\right)$ for determination of total $\mathrm{P}, \mathrm{K}, \mathrm{Ca}, \mathrm{Mg}, \mathrm{Na}, \mathrm{Fe}, \mathrm{Mn}, \mathrm{Zn}$ and $\mathrm{Cu}$. From the digested extractant, Total $\mathrm{P}$ was determined by spectrophotometer method, total $\mathrm{K}$ and $\mathrm{Na}$ by flame - photometer method, total $\mathrm{Ca}$ and $\mathrm{Mg}$ by versenate titration method as described by Jackson (1973). Total Fe, Mn, Zn and Cu were determined on an Atomic Absorption Spectrophotometer. The C: $\mathrm{N}$ ratio was computed from total organic carbon and total $\mathrm{N}$. The results were expressed on dry weight basis. Nutrient contents of various raw materials used for the excrement are given in Table 1.

\section{RESULTS AND DISCUSSIONS}

The status of $\mathrm{pH}, \mathrm{EC}$, Organic carbon, total $\mathrm{N}$ and $\mathrm{C} / \mathrm{N}$ ratio of prepared organic product (vermicompost) under different treatments are presented in Table-2. The results revealed that the differences in PH and EC of end products under varying treatments in individual years were significant. However, in pooled the differences in both the parameters as to varying treatments were non-significant. Results further revealed that during each individual year as well as in pooled significantly the lowest $\mathrm{C}: \mathrm{N}$ ratio and the highest total Nitrogen content were obtained under $\mathrm{T}_{6}$ treatments. i.e. under $50 \%$ $(\mathrm{w} / \mathrm{w})$ cattle dung $+50 \%(\mathrm{w} / \mathrm{w})$ banana pseudo stem $+5 \%(\mathrm{w} / \mathrm{w})$ rock phosphate treatment followed by $\mathrm{T}_{11}$ i.e. $50 \%(\mathrm{w} / \mathrm{w})$ cattle dung $+25 \%(\mathrm{w} / \mathrm{w})$ sugarcane trash $+25 \%(\mathrm{w} / \mathrm{w})$ banana pseudo stem $+5 \%(\mathrm{w} / \mathrm{w})$ rock phosphate treatment. Significantly the highest $\mathrm{N}$ content (3.22\%) and the lowest $\mathrm{C}$ : $\mathrm{N}$ ratio (13:1) was recorded under $\mathrm{T}_{6}$ treatment. As compost / vermicompost with C: $\mathrm{N}$ ratio around 20:1 or below are considered quite suitable as good organic source for application to plant, the treatments $T_{6}$ followed by $T_{11}$. However, end product (vermicompost) prepared under $T_{6}$ was found superior over others in respect of lower $\mathrm{C}$ : $\mathrm{N}$ ratio and higher $\mathrm{N}$ content.

In case of total content (\%) of $\mathrm{P}, \mathrm{K}, \mathrm{Ca}, \mathrm{Mg}$ and $\mathrm{Na}$ ( Table 3), it was noticed that in pooled data, significantly the highest total $\mathrm{P}, \mathrm{K}, \mathrm{Ca}, \mathrm{Mg}$ and $\mathrm{Na}$ were obtained under $\mathrm{T}_{8}, \mathrm{~T}_{3}$ or $\mathrm{T}_{5}, \mathrm{~T}_{4}, \mathrm{~T}_{9}$ and $\mathrm{T}_{4}$ or $\mathrm{T}_{8}$ treatments respectively. But, neither $\mathrm{T}_{6}$ nor $\mathrm{T}_{11}$ treatment depicted the highest total content of $\mathrm{P}, \mathrm{K}, \mathrm{Ca}, \mathrm{Mg}$ and $\mathrm{Na}$. However, the content of these nutrients in 
these two end products was such, as might be used as a good source of these nutrients.

Total content (ppm) of $\mathrm{Fe}, \mathrm{Mn}, \mathrm{Zn}$ and $\mathrm{Cu}$ in prepared vermicomposts under varying treatments are presented in Table-4. The result revealed that in Poole, significantly higher total $\mathrm{Fe}, \mathrm{Mn}, \mathrm{Zn}$ and $\mathrm{Cu}$ were recorded under $\mathrm{T}_{4}, \mathrm{~T}_{2}, \mathrm{~T}_{8}$ and $\mathrm{T}_{3}$ treatments respectively. However, in pooled data it was found that with respect to total Fe, Mn content treatments $\mathrm{T}_{4}$ and $\mathrm{T}_{6}$ were statistically at par. Total $\mathrm{Zn}$ and $\mathrm{Cu}$ contents though showed a significantly higher magnitude under $\mathrm{T}_{5} / \mathrm{T}_{8}$ and $\mathrm{T}_{3}$ respectively, contents of these nutrients under prepared vermicompost were quite sufficient under $\mathrm{T}_{6}$. Results further indicated that vermicomposts having the comparatively lower $\mathrm{C}$ : $\mathrm{N}$ ratio with higher total in $\mathrm{N}$ content though did not exhibit the highest magnitude of these micro nutrients, yet their contents were quite good to serve as organic source.

The total content of some heavy metals $(\mathrm{Co}, \mathrm{Cd}, \mathrm{Pb}$ and $\mathrm{Ni})$ in vermicomposts under varying treatments are presented in Table 5. The Result of pooled data revealed that significantly the lowest content of Co was observed in $\mathrm{T}_{11}$ treatment. In case of $\mathrm{Cd}$, significantly the lowest value was recorded under $\mathrm{T}_{1}$, remaining in par with $\mathrm{T}_{6}$. Similarly, in pooled data revealed that the lowest value of $\mathrm{Pb}$ was recorded in vermicompost under $\mathrm{T}_{1}$ treatment, remaining at par with $\mathrm{T}_{6}, \mathrm{~T}_{7} \mathrm{~T}_{9}$ and $\mathrm{T}_{12}$ treatments. In case of $\mathrm{Ni}$, significantly the lowest value was recorded in vermicompost under $\mathrm{T}_{10}$, which remained at par with $\mathrm{T}_{6}$.

When treatment $\mathrm{T}_{6}$ was compared with $\mathrm{T}_{11}$, with respect to $\mathrm{N}$ content, $\mathrm{C}: \mathrm{N}$ ratio, macro and micro nutrients and heavy metals, it was observed that the vermicompost prepared under $\mathrm{T}_{6}$ i.e. $50 \%(\mathrm{w} / \mathrm{w}$ ) cattle dung $+50 \%$ (w/w) banana pseudo stem $+5 \%(\mathrm{w} / \mathrm{w})$ rock phosphate treatment had higher $\mathrm{N}$ content, comparatively lower C: $\mathrm{N}$ ratio, marginally adequate macro, secondary, micro nutrients along with significantly low heavy metal content ( $\mathrm{Cd}, \mathrm{Pb}$ and $\mathrm{Ni})$ as compared to manure prepared under $\mathrm{T}_{11}$ i.e. $50 \%(\mathrm{w} / \mathrm{w})$ cattle dung $+25 \%(\mathrm{w} / \mathrm{w})$ sugarcane trash $+25 \%(\mathrm{w} / \mathrm{w})$ banana pseudo stem $+5 \%(\mathrm{w} / \mathrm{w})$ rock phosphate treatment. However, significantly the lowest Co was recorded in manure prepared under $\mathrm{T}_{11}$. Hence, vermicompost prepared under treatment $\mathrm{T}_{6}$ was considered as the most superior over others followed by manure (vermicompost) prepared under $\mathrm{T}_{11}$.

The results clearly indicated that organic products having $\mathrm{C}: \mathrm{N}$ ratio $>20$ in other treatments generally pointed to their less maturity which would necessitate continuance of vermicomposting process for longer period for good maturity.

\section{CONCLUSIONS}

Thus, It can be concluded that, for conversion of banana pseudo stem into organic wealth i.e., superior quality vermicompost, "banana pseudo stem chopped to 2-3 mm size (50\% w/w), along 7-10 days old cattle dung (50\% w/w) and rock phosphate $(5 \% \mathrm{w} / \mathrm{w})$ ", must be partially decomposed for one month by decomposting cultural slurry and subsequently be allowed for vermicomposting for 55 days. The material produced this way can fruitfully be utilized as organic manure in agriculture. In case, both sugarcane trash and banana pseudo stem plant wastes are to be converted in to good quality vermicompost, then "25\% (w/w) sugarcane trash $+25 \%(\mathrm{w} / \mathrm{w})$ banana pseudo stem both chopped to 2-3 mm size along with $50 \%(\mathrm{w} / \mathrm{w})$ cattle dung and $5 \%(\mathrm{w} / \mathrm{w})$ rock phosphate" must be partially decomposed for one month and subsequently be allowed for vermicomposting.

\section{REFERENCES}

1. Das Amaresh (2007). Composting with environmental protection. Agriculture Today, October, pp 22-24

2. Jackson, M. L. (1973) Soil Chemical Analysis, Prentice Hall of India Pvt. Ltd, New Delhi. 
3. Trivedi B. S., Patel G. G., Desai R. M. And Padhiyar G. M. (1999) Comparision of Kjeldahl's and Chromic Acid Method of nitrogen determination. GAU Res. J, 25(1) : 9-14

Table 1: Chemical Composition of Different Raw Materials/ Substrates

\begin{tabular}{|c|c|c|c|c|c|c|c|c|c|c|c|c|c|c|c|}
\hline \multirow[t]{2}{*}{ Raw Materials } & OC & $\mathbf{N}$ & $\mathbf{P}$ & $\mathbf{K}$ & $\mathrm{Ca}$ & Mg & $\mathbf{N a}$ & $\mathrm{Fe}$ & Mn & Zn & $\mathrm{Cu}$ & Co & Cd & Pd & $\mathbf{N i}$ \\
\hline & \multicolumn{7}{|c|}{----------------------------------(\%)------------ } & \multicolumn{8}{|c|}{ - } \\
\hline $\begin{array}{l}\text { Subabul } \\
\text { Leaves/Twigs }\end{array}$ & 89 & 3.38 & 0.194 & 1.68 & 2.72 & 0.67 & 0.62 & 981 & 170 & 33 & 17 & 2.6 & 0.7 & 0 & 23.1 \\
\hline $\begin{array}{l}\text { Banana } \\
\text { Pseudostem }\end{array}$ & 92 & 0.72 & 0.31 & 2.94 & 2.24 & 0.77 & 0.39 & 374 & 308 & 55 & 19 & 44.8 & 0 & 34.6 & 0 \\
\hline S' Trash & 93 & 0.57 & 0.09 & 0.52 & 0.64 & 0.19 & 0.42 & 291 & 88 & 27 & 7 & 6.8 & 3.1 & 41.2 & 46.2 \\
\hline Fish Meal & - & 5.63 & 0.96 & 0.94 & 1.92 & 1.06 & 1.82 & 2559 & 163 & 82 & 25 & 31 & 4.6 & 46 & 0.44 \\
\hline Cattle Dang & 74 & 0.34 & 0.2 & 0.79 & 1.76 & 1.06 & 0.58 & 1853 & 238 & 208 & 33 & 16 & 4.4 & 49 & 4.2 \\
\hline Rock Phosphate & - & 0.34 & 7.26 & 1.92 & - & - & 1.72 & 18256 & 1126 & 181 & 34.4 & 35 & 268 & 1075 & - \\
\hline
\end{tabular}

Table 2: pH, EC, OC, N and C: N Ratio of End Product (Vermicompost) Under Different Treatments

\begin{tabular}{|c|c|c|c|c|c|c|c|c|c|c|c|c|c|c|c|}
\hline \multirow[t]{2}{*}{ Treatment } & \multicolumn{3}{|c|}{ pH(1:10) } & \multicolumn{3}{|c|}{ EC $(1: 10)$} & \multicolumn{3}{|c|}{$\mathrm{OC}(\%)$} & \multicolumn{3}{|c|}{ N (\%) } & \multicolumn{3}{|c|}{ C:N ratio } \\
\hline & 2008 & 2009 & Pooled & 2008 & 2009 & Pooled & 2008 & 2009 & Pooled & 2008 & 2009 & Pooled & 2008 & 2009 & Pooled \\
\hline T1 & 8.05 & 7.44 & 7.75 & 2.03 & 1.60 & 1.81 & 58 & 49 & 54 & 1.33 & 1.44 & 1.39 & 43.60 & 34.00 & 39.00 \\
\hline $\mathrm{T} 2$ & 8.03 & 7.26 & 7.66 & 2.10 & 1.75 & 1.92 & 55 & 49 & 52 & 1.45 & 1.51 & 1.48 & 37.90 & 32.50 & 35.00 \\
\hline T3 & 7.27 & 7.38 & 7.33 & 3.76 & 1.55 & 2.66 & 64 & 60 & 62 & 1.64 & 1.75 & 1.70 & 39.10 & 34.30 & 37.00 \\
\hline T4 & 7.70 & 7.24 & 7.47 & 2.23 & 1.46 & 1.85 & 47 & 40 & 43 & 1.87 & 1.93 & 1.90 & 25.10 & 20.70 & 23.00 \\
\hline T5 & 8.16 & 7.07 & 7.62 & 2.63 & 2.00 & 2.32 & 65 & 59 & 62 & 1.37 & 1.42 & 1.40 & 47.60 & 41.60 & 45.00 \\
\hline T6 & 7.30 & 7.41 & 7.36 & 2.57 & 1.60 & 2.09 & 45 & 38 & 41 & 3.19 & 3.25 & 3.22 & 14.10 & 11.70 & 13.00 \\
\hline T7 & 7.30 & 7.56 & 7.43 & 2.27 & 1.44 & 1.85 & 55 & 48 & 51 & 2.13 & 2.19 & 2.16 & 25.80 & 21.90 & 24.00 \\
\hline T8 & 7.69 & 7.38 & 7.54 & 2.40 & 1.98 & 2.19 & 64 & 55 & 59 & 1.57 & 1.64 & 1.61 & 40.70 & 33.60 & 37.00 \\
\hline T9 & 7.52 & 7.47 & 7.49 & 2.23 & 1.51 & 1.87 & 55 & 48 & 52 & 2.24 & 2.28 & 2.26 & 24.60 & 21.07 & 23.00 \\
\hline T10 & 7.88 & 7.20 & 7.54 & 2.43 & 1.74 & 2.09 & 51 & 44 & 47 & 1.92 & 1.99 & 1.96 & 26.60 & 22.10 & 24.00 \\
\hline T11 & 7.39 & 7.41 & 7.40 & 2.33 & 1.61 & 1.97 & 51 & 44 & 47 & 2.34 & 2.42 & 2.38 & 21.80 & 18.20 & 20.00 \\
\hline $\mathrm{T} 12$ & 7.88 & 7.37 & 7.63 & 2.63 & 1.72 & 2.18 & 58 & 51 & 55 & 1.63 & 1.73 & 1.68 & 35.60 & 29.40 & 33.00 \\
\hline Sem+- & 0.017 & 0.007 & 0.21 & 0.04 & 0.01 & 0.24 & 0.75 & 0.69 & 0.53 & 0.05 & 0.05 & 0.03 & 1.16 & 0.71 & 0.73 \\
\hline CD $0.05 \%$ & 0.05 & 0.021 & NS & 0.1 & 0.01 & NS & 2.18 & 2.03 & 1.51 & 0.14 & 0.14 & 0.09 & 3.38 & 2.06 & 2.09 \\
\hline YXT & - & - & 0.04 & - & - & 0.07 & - & - & NS & - & - & NS & - & - & NS \\
\hline $\mathrm{CV} \%$ & 0.39 & 0.17 & 0.3 & 2.43 & 0.5 & 2.08 & 2.33 & 2.47 & 2.4 & 4.43 & 4.34 & 4.39 & 6.29 & 4.56 & 5.66 \\
\hline
\end{tabular}

Table 3: Total P, K, Ca, Mg and Na Content of End Product (Vermicompost) Under Different Treatments

\begin{tabular}{|c|c|c|c|c|c|c|c|c|c|c|c|c|c|c|c|}
\hline \multirow[b]{2}{*}{ Treatments } & \multicolumn{3}{|c|}{$\mathbf{P}(\%)$} & \multicolumn{3}{|c|}{$\mathbf{K}(\%)$} & \multicolumn{3}{|c|}{$\mathrm{Ca}$} & \multicolumn{3}{|c|}{ Mg } & \multicolumn{3}{|c|}{$\mathrm{Na}$} \\
\hline & 2008 & 2009 & Pooled & 2008 & 2009 & Pooled & 2008 & 2009 & Pooled & 2008 & 2009 & Pooled & 2008 & 2009 & Pooled \\
\hline $\mathrm{T}_{1}$ & 0.95 & 1.01 & 0.98 & 0.57 & 0.62 & 0.59 & 1.09 & 1.17 & 1.13 & 1.85 & 1.99 & 1.92 & 0.76 & 0.71 & 0.73 \\
\hline $\mathrm{T}_{2}$ & 1.87 & 2.01 & 1.94 & 0.58 & 0.62 & 0.60 & 2.23 & 2.26 & 2.24 & 2.04 & 2.11 & 2.07 & 0.75 & 0.70 & 0.72 \\
\hline$T_{3}$ & 2.00 & 2.11 & 2.06 & 0.71 & 0.75 & 0.73 & 2.21 & 2.26 & 2.23 & 2.15 & 2.24 & 2.20 & 0.91 & 0.86 & 0.88 \\
\hline$T_{4}$ & 1.64 & 1.71 & 1.68 & 0.64 & 0.69 & 0.66 & 3.12 & 3.14 & 3.13 & 2.03 & 2.12 & 2.08 & 0.99 & 0.89 & 0.94 \\
\hline$T_{5}$ & 1.68 & 1.72 & 1.70 & 0.70 & 0.75 & 0.73 & 2.27 & 2.29 & 2.28 & 2.23 & 2.31 & 2.27 & 0.75 & 0.70 & 0.72 \\
\hline$T_{6}$ & 1.36 & 1.41 & 1.38 & 0.59 & 0.65 & 0.62 & 2.93 & 3.00 & 2.97 & 2.46 & 2.53 & 2.49 & 0.83 & 0.78 & 0.80 \\
\hline $\mathrm{T}_{7}$ & 2.12 & 2.17 & 2.15 & 0.58 & 0.74 & 0.66 & 2.45 & 2.49 & 2.47 & 2.22 & 2.28 & 2.25 & 0.93 & 0.88 & 0.90 \\
\hline$T_{8}$ & 2.37 & 2.47 & 2.42 & 0.68 & 0.65 & 0.66 & 2.46 & 2.50 & 2.48 & 2.44 & 2.53 & 2.48 & 0.97 & 0.92 & 0.94 \\
\hline$T_{9}$ & 2.10 & 2.17 & 2.14 & 0.59 & 0.64 & 0.61 & 2.99 & 3.08 & 3.03 & 2.65 & 2.76 & 2.70 & 0.92 & 0.87 & 0.90 \\
\hline $\mathrm{T}_{10}$ & 1.55 & 1.61 & 1.58 & 0.58 & 0.66 & 0.62 & 2.76 & 2.83 & 2.79 & 2.33 & 2.39 & 2.36 & 0.87 & 0.83 & 0.85 \\
\hline $\mathrm{T}_{11}$ & 1.28 & 1.34 & 1.31 & 0.61 & 0.60 & 0.60 & 2.92 & 3.08 & 3.00 & 1.93 & 1.73 & 1.83 & 0.82 & 0.77 & 0.80 \\
\hline $\mathrm{T}_{12}$ & 1.10 & 1.14 & 1.12 & 0.54 & 0.64 & 0.59 & 1.70 & 1.81 & 1.76 & 2.07 & 2.14 & 2.11 & 0.61 & 0.57 & 0.59 \\
\hline Sem \pm & 0.03 & 0.02 & 0.017 & 0.01 & 0.01 & 0.024 & 0.07 & 0.04 & 0.04 & 0.03 & 0.10 & 0.05 & 0.03 & 0.03 & 0.017 \\
\hline $\mathbf{C D}_{0.05 \%}$ & 0.09 & 0.05 & 0.048 & 0.04 & 0.02 & 0.077 & 0.2 & 0.12 & 0.11 & 0.09 & 0.29 & 0.14 & 0.08 & 0.08 & 0.048 \\
\hline YXT & - & - & NS & - & - & 0.031 & - & - & NS & - & - & NS & - & - & NS \\
\hline CV\% & 3.11 & 1.77 & 2.50 & 3.86 & 1.66 & 2.89 & 4.95 & 2.78 & 3.99 & 2.36 & 7.59 & 5.69 & 5.36 & 5.86 & 5.61 \\
\hline
\end{tabular}


Table-4: Total Fe, Mn, Zn and Cu Content (Ppm) of End Product (Vermicompost) Under Different Treatments

\begin{tabular}{|c|c|c|c|c|c|c|c|c|c|c|c|c|c|c|c|}
\hline \multirow[b]{2}{*}{ Treatments } & \multicolumn{3}{|c|}{$\mathrm{P}(\%)$} & \multicolumn{3}{|c|}{$\mathbf{K}(\%)$} & \multicolumn{3}{|c|}{$\mathrm{Ca}$} & \multicolumn{3}{|c|}{ Mg } & \multicolumn{3}{|c|}{$\mathrm{Na}$} \\
\hline & 2008 & 2009 & Pooled & 2008 & 2009 & Pooled & 2008 & 2009 & Pooled & 2008 & 2009 & Pooled & 2008 & 2009 & Pooled \\
\hline $\mathrm{T}_{1}$ & 0.95 & 1.01 & 0.98 & 0.57 & 0.62 & 0.59 & 1.09 & 1.17 & 1.13 & 1.85 & 1.99 & 1.92 & 0.76 & 0.71 & 0.73 \\
\hline $\mathrm{T}_{2}$ & 1.87 & 2.01 & 1.94 & 0.58 & 0.62 & 0.60 & 2.23 & 2.26 & 2.24 & 2.04 & 2.11 & 2.07 & 0.75 & 0.70 & 0.72 \\
\hline $\mathrm{T}_{3}$ & 2.00 & 2.11 & 2.06 & 0.71 & 0.75 & 0.73 & 2.21 & 2.26 & 2.23 & 2.15 & 2.24 & 2.20 & 0.91 & 0.86 & 0.88 \\
\hline $\mathrm{T}_{4}$ & 1.64 & 1.71 & 1.68 & 0.64 & 0.69 & 0.66 & 3.12 & 3.14 & 3.13 & 2.03 & 2.12 & 2.08 & 0.99 & 0.89 & 0.94 \\
\hline $\mathrm{T}_{5}$ & 1.68 & 1.72 & 1.70 & 0.70 & 0.75 & 0.73 & 2.27 & 2.29 & 2.28 & 2.23 & 2.31 & 2.27 & 0.75 & 0.70 & 0.72 \\
\hline $\mathrm{T}_{6}$ & 1.36 & 1.41 & 1.38 & 0.59 & 0.65 & 0.62 & 2.93 & 3.00 & 2.97 & 2.46 & 2.53 & 2.49 & 0.83 & 0.78 & 0.80 \\
\hline $\mathrm{T}_{7}$ & 2.12 & 2.17 & 2.15 & 0.58 & 0.74 & 0.66 & 2.45 & 2.49 & 2.47 & 2.22 & 2.28 & 2.25 & 0.93 & 0.88 & 0.90 \\
\hline $\mathrm{T}_{8}$ & 2.37 & 2.47 & 2.42 & 0.68 & 0.65 & 0.66 & 2.46 & 2.50 & 2.48 & 2.44 & 2.53 & 2.48 & 0.97 & 0.92 & 0.94 \\
\hline $\mathrm{T}_{9}$ & 2.10 & 2.17 & 2.14 & 0.59 & 0.64 & 0.61 & 2.99 & 3.08 & 3.03 & 2.65 & 2.76 & 2.70 & 0.92 & 0.87 & 0.90 \\
\hline $\mathrm{T}_{10}$ & 1.55 & 1.61 & 1.58 & 0.58 & 0.66 & 0.62 & 2.76 & 2.83 & 2.79 & 2.33 & 2.39 & 2.36 & 0.87 & 0.83 & 0.85 \\
\hline $\mathrm{T}_{11}$ & 1.28 & 1.34 & 1.31 & 0.61 & 0.60 & 0.60 & 2.92 & 3.08 & 3.00 & 1.93 & 1.73 & 1.83 & 0.82 & 0.77 & 0.80 \\
\hline $\mathrm{T}_{12}$ & 1.10 & 1.14 & 1.12 & 0.54 & 0.64 & 0.59 & 1.70 & 1.81 & 1.76 & 2.07 & 2.14 & 2.11 & 0.61 & 0.57 & 0.59 \\
\hline $\operatorname{Sem} \pm$ & 0.03 & 0.02 & 0.017 & 0.01 & 0.01 & 0.024 & 0.07 & 0.04 & 0.04 & 0.03 & 0.10 & 0.05 & 0.03 & 0.03 & 0.017 \\
\hline $\mathrm{CD}_{0.05 \%}$ & 0.09 & 0.05 & 0.048 & 0.04 & 0.02 & 0.077 & 0.2 & 0.12 & 0.11 & 0.09 & 0.29 & 0.14 & 0.08 & 0.08 & 0.048 \\
\hline YXT & - & - & NS & - & - & 0.031 & - & - & NS & - & - & NS & - & - & NS \\
\hline CV\% & 3.11 & 1.77 & 2.50 & 3.86 & 1.66 & 2.89 & 4.95 & 2.78 & 3.99 & 2.36 & 7.59 & 5.69 & 5.36 & 5.86 & 5.61 \\
\hline
\end{tabular}

Table-5: Total Co, Cd, Pb and Ni Content (Ppm) of End Product (Vermicompost) Under Different Treatments

\begin{tabular}{|c|c|c|c|c|c|c|c|c|c|c|c|c|}
\hline \multirow{2}{*}{ Treatments } & \multicolumn{3}{|c|}{ Co } & \multicolumn{3}{|c|}{ Cd } & \multicolumn{3}{|c|}{$\mathbf{P b}$} & \multicolumn{3}{|c|}{$\mathrm{Ni}$} \\
\hline & 2008 & 2009 & Pooled & 2008 & 2009 & Pooled & 2008 & 2009 & Pooled & 2008 & 2009 & Pooled \\
\hline$T_{1}$ & 28 & 30 & 29 & 3.9 & 4.6 & 4.3 & 4.3 & 5.8 & 5.03 & 41 & 46 & 43 \\
\hline $\mathbf{T}_{2}$ & 31 & 33 & 32 & 10.9 & 12.7 & 11.8 & 11.3 & 13.2 & 12.3 & 56 & 57 & 57 \\
\hline$T_{3}$ & 28 & 30 & 29 & 5.3 & 6.1 & 5.7 & 6.6 & 9.1 & 7.8 & 55 & 59 & 57 \\
\hline $\mathbf{T}_{4}$ & 32 & 34 & 33 & 7.3 & 8.1 & 7.7 & 9.6 & 11.2 & 10.4 & 47 & 53 & 50 \\
\hline$T_{5}$ & 32 & 34 & 33 & 6.9 & 7.1 & 7.0 & 9.3 & 10.7 & 10.0 & 69 & 74 & 72 \\
\hline$T_{6}$ & 31 & 35 & 33 & 4.8 & 5.5 & 5.1 & 5.3 & 6.1 & 5.7 & 66 & 38 & 36 \\
\hline $\mathbf{T}_{7}$ & 24 & 26 & 25 & 5.7 & 6.2 & 5.9 & 5.0 & 6.3 & 5.7 & 47 & 55 & 51 \\
\hline $\mathbf{T}_{8}$ & 31 & 33 & 32 & 8.2 & 8.9 & 8.5 & 6.7 & 8.1 & 7.4 & 46 & 44 & 42 \\
\hline$T_{9}$ & 24 & 27 & 26 & 7 & 7.5 & 7.2 & 5.4 & 6.5 & 6.0 & 37 & 41 & 39 \\
\hline$T_{10}$ & 30 & 32 & 31 & 6.8 & 7.7 & 7.2 & 8.4 & 10.1 & 9.3 & 34 & 36 & 35 \\
\hline$T_{11}$ & 17 & 18 & 17 & 5.6 & 6.2 & 5.9 & 5.8 & 7.2 & 6.5 & 34 & 41 & 37 \\
\hline$T_{12}$ & 26 & 28 & 27 & 5.2 & 5.8 & 5.5 & 5.4 & 6.3 & 5.8 & 47 & 51 & 49 \\
\hline Sem + & 1.57 & 1.28 & 0.92 & 0.47 & 0.5 & 0.32 & 0.69 & 0.44 & 0.38 & 5.66 & 1.73 & 2.7 \\
\hline $\mathrm{CD}_{0.05 \%}$ & 4.58 & 3.75 & 2.6 & 1.38 & 1.45 & 0.91 & 2.02 & 1.27 & 1.08 & 16.53 & 5.04 & 7.63 \\
\hline YXT & - & - & NS & - & - & NS & - & - & NS & - & - & NS \\
\hline CV\% & 9.77 & 7.45 & 8.61 & 12.7 & 11.9 & 12.3 & 17.3 & 9.02 & 13.1 & 21.9 & 6.04 & 15.4 \\
\hline
\end{tabular}

